\title{
ANALISIS STRATEGI MENINGKATKAN KEPUASAN NASABAH TABUNGAN PADA \\ PT. BANK RAKYAT INDONESIA (Persero) Tbk. \\ KCP BAMBALOKA
}

\author{
Oleh \\ Muhammad Ikhsan \\ Institut Bisnis dan Keuangan Nitro Makassar \\ Email : muhammadikhsaniccang98@gmail.com
}

\begin{abstract}
Abstrak
Tujuan penelian ini adalah untuk mengetahui dan menganalisisstrategi yang di gunakan PT. Bank Republik Indonesia (Persero) Tbk. Kcp Bambaloka untuk meningkatkan kepuasan nasabah tabungan.

Jenis data yang digunakan dalam penelitian ini adalah Data kualitatif berupa hasil wawancara yang terkait dengan penelitian.

Kata Kunci: Strategi, Kepuasaan nasabah, Kepuasaan pelanggan
\end{abstract}

\section{PENDAHULUAN}

PT Bank Rakyat Indonesia (Persero), Tbk (BRI atau Bank BRI) adalah salah satu bank milik pemerintah terbesar di Indonesia. Sebagai bank tertua, BRI tetap konsisten dalam memberikan pelayanan kepada segmen usaha mikro, kecil dan menengah (UMKM) dan komitmen ini terus berlanjut pada saat BRI menjadi perusahaan publik pada tahun 2003 hingga sekarang.

Kepuasan nasabah merupakan aset yang penting bagi perusahaan karena dapat digunakan sebagai indikator atas kualitas dan pendapatan perusahaan dimasa 
mendatang, kepuasan nasabah hasil dari perbandingan antara harapan dan kenyataan yang diterima nasabah setelah mengkomsumsi barang atau jasa.

Tabungan merupakan produk yang paling banyak dipakai oleh nasabah bank karena memiliki kemudahan dalam proses pendaftaran yang mempermudah nasabah dalam menyimpan dananya.

Menurut Marbun (2003), pengertian usaha adalah kegiatan yang dilakukan secara terorganisasi dan terarah untuk mencapai sasaran yang sudah ditentukan secara tetap, baik yang dilakukan secara individu maupun kelompok.

Berdasarkan uraian diatas, yang telah dikemukakan pada latar belakang, maka penulis tertarik untuk melakukan penelitian tentang judul "Analisis Strategi meningkatkan kepuasan nasabah tabungan pada PT. Bank Rakyat Indonesia (Persero) Tbk. Kcp Bambaloka.

\section{TINJAUAN PUSTAKA}

\section{A. LANDASAN TEORI}

1. Strategi
a. Definisi Strategi

Strategi adalah hal penting bagi kelangsungan hidup dari suatu perusahan untuk mencapai sasaran atau tujuan perusahaan yang efektif dan efisien, perusahaan harus bisa menghadapi setiap masalah-masalah atau hambatan 
yang datang dari dalam perusahaan maupun dari luar perusahaan.

Menurut Tjiptono (2006:3) istilah strategi berasal dari bahasa Yunani yaitu strategia yang artinya seni atau ilmu untuk menjadi seorang jendral. Strategi juga bisa diartikan suatu rencana untuk pembagian dan penggunaan kekuatan militer pada daerah-daerah tertentu untuk mencapai tujuan tertentu.

Menurut Jurini (2003: 47) setiap perusahaan menjalankan strategi pemasaran untuk mencapai tujuan yang diharapkan. Ada 3 (tiga) tahap yang ditempuh perusahaan untuk menetapkan strategi pemasaran, yaitu memilih konsumen yang dituju, mengidentifikasi keinginan konsumen, dan menentukan bauran pemasaran. Strategi pemasaran yang berhasil umumnya ditentukan dari satu atau beberapa marketing mix (bauran pemasaran).

b. Strategi Meningkatkan Kepuasaan Pelanggan

Adapun beberapa strategi yang dapat dilakukan dan dipadukan untuk meraih dan meningkatkan kepuasan pelanggan tjiptono menurut (2006:161) yaitu sebagai berikut :

1) Relationship Marketing

Relationship Marketing adalah cara usaha pemasaran pada pelanggan yang meningkatkan pertumbuhan jangka panjang dalam perusahaan dan kepuasan maksimum pelanggan. Pelanggan yang baik merupakan suatu asset dimana bila ditangani dan dilayani dengan baik akan memberikan pendapatan dan pertumbuhan jangka panjang bagi suatu perusahaan. 
Menurut Chan (2003:87) Strategi relationship marketing dapat dijalankan dengan baik apabila pelanggan yang dimiliki oelh perusahaan mempunyai persyaratan sebagai berikut:

a) Pelanggan dimasing peringkat apabila mempunyai profil berbeda antara satu dengan yang lain.

b) Pelanggan pada masing peringkat apabila bisa memberi value (nilai) secara proporsional terhadap pelayanan yang diterimanya, perusahaan lebih senang untuk melayani pelanggan istimewa yang menginginkan kecepatan pelayanan dan personalitas sebagai atribut yang diproritaskan dibandingkan pelanggan biasa, yang lebih mementingkan harga murah.

c) Pelanggan pada masing peringkat apabila memiliki perbedaan dalam pemberian respon atau tanggapan terhadap setiap penawaran perusahaan.

\section{2) Strategi Superior Customer Service}

Perusahaan yang menerapkan strategi ini perusahaan menawarkan penawarkan pelayanan yang lebih unggul dari para pesaingnya.Kemampuan sumber daya manusia dan usaha yang gigih meskipun demikian,melalui pelayanan yang unggul, perusahaan yang bersangkutan dapat membebankan harga yang lebih tinggi pada jasanya. Akan ada kelompok konsumen yang tidak keberatan akan harga mahal tersebut. Impementasinya yaitu, pemberian garansi internal dan eksternal, jaminan, konsultasi teknis, pelatihan cara penggunaan produk, saran pemakaian produk alternative, peluang penukaran atau pembelian produk yang tidak memuaskan, reparasi komponen yang cacat atau rusak dan penyediaan suku cadang pengganti. 
Guarantees/extraordinary Guarantes Untuk meningkatkan kepuasan pelanggan, perusahaan jasa dapat mengembangkan augmented service terhadap core service-nya, misalnya dengan merancang garansi tertentu atau dengan memberikan pelayanan purna jual yang baik. Garansi atau jaminan istimewa dirancang untuk meringankan kerugian pelanggan, dalam hal pelanggan tidak puas terhadap suatu produk atau jasa yang telah dibayarkan.

a) Untuk mengurangi resiko kerugian pelanggan sebelum dan sesudah pembelian produk atau jasa.

b) Sebagai alat positioning untuk membedakan perusahaan dengan pesaingnya.

4) Strategi Penanganan Keluhan Pelanggan yang Efektif

Penanganan keluhan yang baik memberikan peluang untuk mengubah seorang pelanggan yang tidak puas menjadi pelanggan yang puas. Manfaat lain adalah:

a). Penyedia jasa memperoleh kesempatan lagi untuk memperbaiki hubungannya dengan pelanggan yang kecewa.

b). Penyedia jasa bisa terhindar dari publisitas negatif.

c) Penyedia jasa akan mengetahui aspek yang perlu dibenahi dalam pelayanannya saat ini.

d) Penyedia jasa akan mengetahui sumber masalah operasinya.

e) Karyawan dapat termotivasi untuk memberikan pelayanan yang berkualitas lebih baik. 


\section{Kepuasan nasabah}

Salah satu tujuan utama perusahaan jasa dalam hal ini adalah menciptakan kepuasan nasabah, sebagai hasil penilaian terhadap apa yang diharapkannya dengan membeli dan mengomsumsi suatu produk atau jasa.

Menurut Kotler (2003:70) menyatakan bahwa kepuasan merupakan tingkat kepuasaan dimana seseorang menyatakan hasil perbandingan antara hasil kerja atau produk atau jasa yang diterima dengan apa yang diharapkan.

Menurut Kasmir (2008:237) kepuasan nasabah menjadi sangat bernilai bagi Bank atau perusahaaan sehingga tidak heran selalu ada slogan bahwa pelanggan adalah raja yang diperlu dilayani sebaik-baiknnya.

\section{Kepuasan pelanggan}

Kepuasan pelanggan menurut Kotler and Keller, (2007) adalah tingkat perasaan seseorang setelah membandingkan kinerja peoduk (atau hasil) yang ia rasakan dengan harapan yang kita miliki. Kepuasan merupakan sebuah fungsi dari perbedaan antara kinerja yang dirasakan dan harapan yang didapatkan pada saat pelanggan bisa mengalami salah satu dari tiga tingkat kepuasan yang umum. Kepuasan atau rasa senang yang tinggi menciptakan ikatan emosional dengan merek atau perusahaan tersebut, berakti tingkat kepuasan yang dirasakan pelanggan yang didapatkan pada masa pembelian, pengalaman menggunakan barang atau jasa dan masa setelah pembelian berlangsung. 
Menurut supranto (2001: 231) tingkat kepuasan nasabah sangat tergantu pada mutu/kualitas suatu produk/jasa. Jadi suatu produk/jasa dikatakan bermutu bagi nasabah kalau produk tersebut dapat memenuhi kebutuhannya. Untuk mencapai kepuasan nasabah yang terus meningkat, maka perlu dilakukan atau dilaksanakan hal sebagai berikut :

a. Memperhatikan kualitas pelayanan dari staf bank yang melayani nasabah dengan keramahan, sopan santun serta pelayanan cepat dan efisien, staf bank disini mulai dari staf paling bawah sampai dengan pimpinan tertinggi dibank tersebut.

b. Faktor pendekatan dan kedekatan untuk berinteraksi dengan staf bank tersebut, Nasabah diberlakukan seperti teman lama sehingga timbul keakraban dan kenyamanan selama berhubungan dengan bank.

c. Harga yang ditawarkan, pengertian harga disini untuk bank, yaitu baik bunga simpanan, maupun bunga pinjaman atau baik hasil biaya administrasi yang ditawarkan konpetitif dengan bank lain.

d. Kenyamanan dan keamanan lokasi bank. Sebagai tempat bertransaksi, dalam hal ini nasabah selalu merasakan adanya kenyamanan baik diluar bank maupun di dalam bank.

e. Kemudahan memperoleh produk bank. Artinya jenis produk yang ditawarkan lengkap dan tidak memerlukan prosedur yang berbelit-belit atau persyaratan yang memberatkan seperti misalnya dalam hal permohonan kredit.

f. Penanganan kompain atau keluhan. Artinya setiap ada keluhan atau kompain yang dilakukan nasabah ditanggapi dan ditangani secara cepat dan tepat. 
g. Kelengkapan dan kegunaan produk termasuk kelengkapan fasilitas dan produk yang ditawarkan, misalnya tersedianaya fasilitas ATM diberbagai lokasi strategis.

h. Perhatian terhadap nasabah dimasa mendatang terutama terhadap pelayanan purna jualnya.

Agar kita tahu bahwa nasabah puas atau tidak berhubungan dengan bank, perlu adanya alat ukur untuk menentukan kepuasan nasabah.

Kotler dalam Tjiptono (2003:104) mengidentifikasi 4 metode untuk mengukur kepuasan pelanggan, yaitu sebagai berikut :

1) Sistem keluhan dan saran

Artinya, seberapa banyak keluhan atau kompain yang dilakukan nasabah dalam suatu periode.

2) Survei kepuasan pelanggan

Dalam hal ini bank perlu secara berkala melakukan survei, baik melalui wawancara maupun kuisioner tentang segala sesuatu yang berhubungan dengan bank tempat nasabah melakukan transaksi selama ini. Dan maka dari itu kita perlu survei kepuasan konsumen.

3) Pembeli bayangan

Bank dapat mengirim karyawannya atau melalui orang lain seakan dia menjadi nasabah guna melihat pelayanan yang diberikan oleh karyawan bank secara langsung dan terlihat jelas bagaimana karyawan melayani nasabah sesunggunnya.

4) Analisis pelanggan yang lari

Dengan melihat catatan nasabah yangperna menjadi nasabah bank guna mengetahui mereka tidak lagi menjadi nasabah bank kita. 
Menurut kotler dan keller (2009:140) mempertahankan pelanggan merupakan hal penting daripada memikikat pada karyawan. Oleh karena itu terdapat lima indikator untuk mengukurpada kepuasan pelanggan yaitu:

a) Membeli kembali produk atau jasa, artinya nasabah puas terhadap produk yang ditawarkan.

b) Mengatakan hal yang paling baik tentang perusahaan kepada orang lain merekomendasikan, artinya nasabah puas dengan layanan yang diberikan.

c) Kurang memperhatikan merek dan iklan produk pesaing, artinya nasabah puas terhadap manfaat produk yang dihasilkan.

4. Penelitian terdahulu

Penelitian terdahulu yang mendasarkan penelitian ini diantaranya adalah :

a. Penelitian yang dilakukan oleh Daga R (2017) dengan judul "Strategi meningkatkan kepuasan nasabah tabungan pada PT. Bank Perkreditan Tabungan Hasa Mitra Cabang Makassar". Berdasarkan hasil penelitian adalah strategi yang digunakan PT. Bank Perkreditan Rakyat Hasa Mitra dalam meningkatkan kepuasan nasabah tabungan yaitu, Strategi Superior Custumer Service, Strategi UnconditionalGuarantees dan Strategi Penanganan Keluhan yang efektif. Dari jumlah nasabah tabungan pada PT. Bank Perkreditan Rakyat Hasa Mitra telah terjadi peningkatan jumlah nasabah tabungan tahun 2015. Disini Nampak bahwa strategi pemasaran yang dilakukan telah dapat meningkatkan jumlah nasabah, ini berarti strategi pemasaran yang dilakukan telah efektif dalam meningkatkan jumlah nasabah. 
b. Penelitan yang dilakukan oleh Yusuf (2019) dengan judul "Analisis Tingkat Kepuasan Nasabah Dalam Menggunakan Transaksi Non Tunai Pada PT. Bank Mandiri (Persero) Tbk. Ratulangi, Makassar" Metode analisis yang digunakan adalah metode diagram deskriptif kartesius. Metode ini digunakan untuk menganalisis secara deskriptif kualitas produk jasa, dilihat berdasarkan tingkat kesuaian kualitas produk jasa yang diharapkan dengan kualitas produk jasa yang disarankan.

B. KERANGKA PIKIR

\section{Gambar 2.1}

Kerangka Pikir

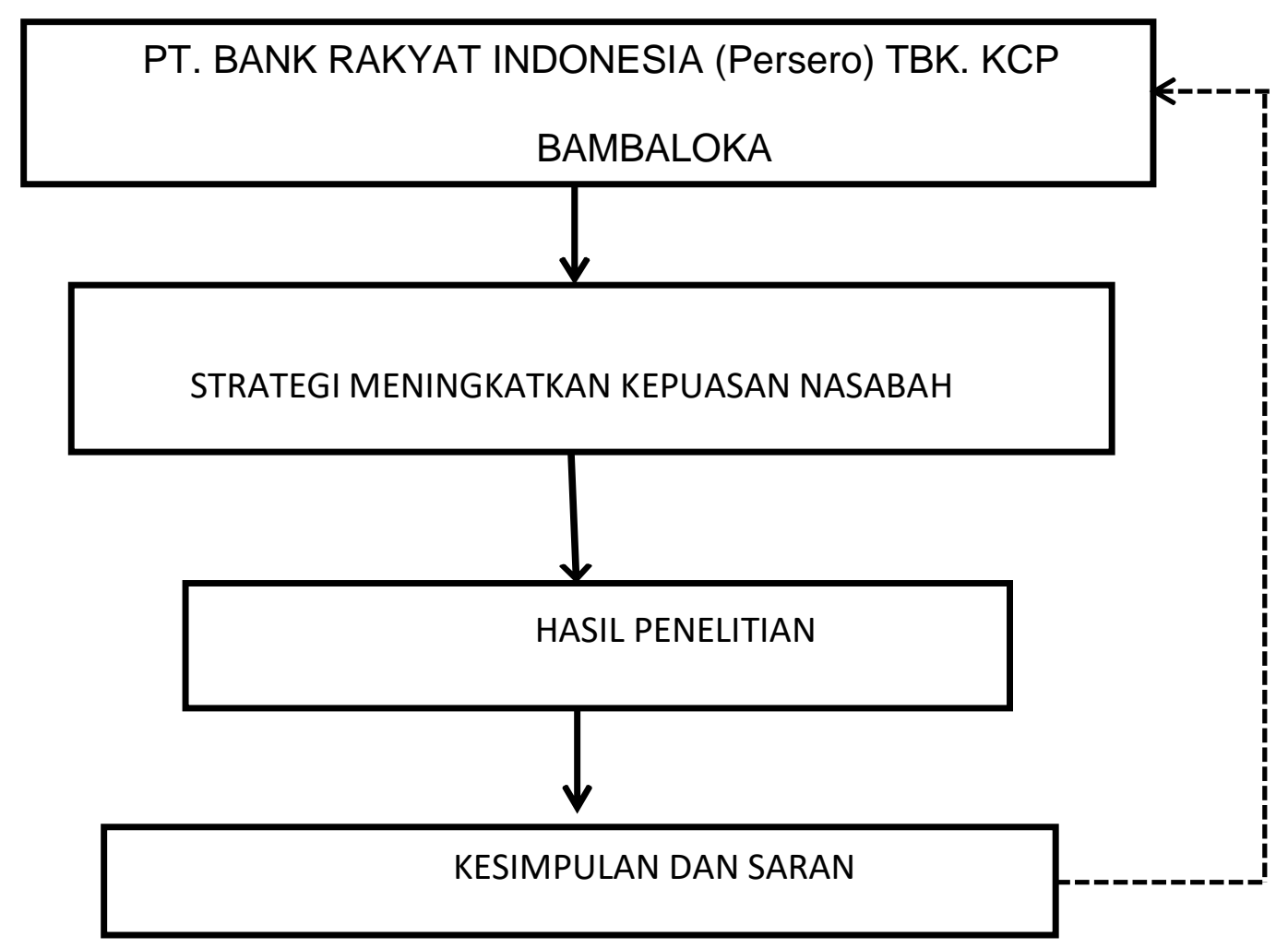


Keterangan :

Perusahaan PT. Bank BRI Kcp Bambaloka adalah lembaga satu jenis bank yang dikenal melayani golongan pengusaha mikro kecil dan menengah. Fungsi BRI tidak hanya sekedar menyalurkan kredit kepada para pengusaha mikro, kecil dan menengah tetapi juga menerima simpanan dana masyarakat dan kemudian menyalurkan dalam kredit. Strategi meningkatkan kepuasan nasabah sangat lah penting bagi perusahaan. Visi dan Misi perusahaan yang telah ditetapkan tentu menjadi acuan bahwa perusahaan harus mampu mencapai semua visi dan misi tersebut. Salah satu upaya yang ingin dicapai adalah dengan melakukan strategi meningkatkan kepuasan nasabah untuk mencapai sebuah sasaran dengan tujuan meningkatkan jumlah nasabah tabungan PT.Bank Rakyat Indonesia (Persero) Tbk.

\section{METODE PENELITIAN}

\section{LOKASI DAN WAKTU PENELITIAN}

Peneliti ini dapat di lakukan pada karyawan PT. Bank Rakyat Indonesia (Persero)

Tbk. Kcp Bambaloka. Yang beralamat Kelurahan Bambaloka, Mamuju Utara,

Sulawesi Barat waktu yang di butuhkan penelitian ini sekitar 1 (satu) bulan.

\section{JENIS DAN SUMBER DATA}

a. Jenis Data

Data yang digunakan dalam penelitian ini adalah Data kualitatif berupa hasil wawancara yang terkait dengan penelitian.

b. Sumber Data

Sumber data pada penelitian ini berupa data primer yang berasal dari wawancara langsung dan observasi dengan informan penelitian. 


\section{TEKNIK PENGUMPULAN DATA}

Teknik pengumpulan data yang digunakan dalam penelitian ini adalah sebagai berikut :

1. Metode Pengumpulan data

Metode pengumpulan data yang digunakan, yaitu:

a. Wawancara

Wawancara merupakan alat cheking atau pembuktian terhadap informasi atau keterangan yang diperoleh sebelumnya. Menurut Esterberg wawancara dalah pertemuan dua orang untuk betukar informasi dan ide melalui tanda jawab, sehingga dapat dikonstruksikan nakna dalam suatu topik tertentu (Sugiyono, 2010:231). Teknik wawancara yang digunakan dalam penelitian kualitatif adalah wawancara mendalam (Indepth interview ) adalah proses memperoleh keterangan untuk tujuan penelitian dengan cara Tanya jawab sambil bertatap muka antara pewawancara dengan informan atau orang yang diwawancara.

b. Observasi

Observasi adalah kegiatan yang melibatkan seluruh kekuatan indera seperti pendengaran, penglihatan, perasaan, sentuhan, dan cita rasa berdasarkan pada fakta-fakta peristiwa empiris, Prinsip umum dalam melakukan observasi adalah pengamat tidak tidak memberikan perlakuan tertentu kepada subjek yang diamati, melainkan membiarkan subjek yang sedang diamati berucap dan bertindak sama persis dengan kegiatan mereka sehari-hari (Anggito dan Setiawab, 2018:142). 


\section{Teknik Pengumpulan Data}

Teknik yang digunakan dalam penelitian ini dapat diuaraikan sebagai berikut :

a. Data kata-kata (Verbal) berupa apa yang dikatakan informan tentang karyawan baruan pemasaran apakah yang digunakan dalam meningkatkan kepuasan nasabah tabungan pada PT. Bank Rakyat Indonesia (Persero) Tbk. Kcp Bambaloka.

b. Data non verbal merupakan apa yang telah difikirkan, dipercaya, diketahui, dan disikapi, oleh informan dalam kegiatannya.

c. Data fotografi data ini membantu memberikan gambaran sesuai perilaku.

Teknik pengumpulan data dilakukan melalui wawancara secara mendalam dengan instrumen yang tidak terstruktur. Lamanya waktu wawancara tidak dibatasi. Namun tetap memperhatikan etika dan kondisi informan. Meskipun instrumen wawancara tidak terstruktur, Peneliti menyiapkan konsep yang akan ditanyakan, namun dalam prakteknya peneliti akan membuat wawancara mengalir dan berkembang. Teknik pengumpulan data non verbal dilakukan melalui observasi dan dokumentasi. Peneliti ini akan dibantu oleh kamera, perekam suara, dan catatan harian observasi. 


\section{INFORMASI PENELITIAN}

Pada penelitian kualitatif, tidak dikenal adanya populasi dan sampel, tetapi dinamakan informan. Informan adalah orang diberikan pertanyaan untuk mendapatkan informasi mengenai fokus penelitian. Informan ditentukan dengan teknik purvosive, yaitu teknik penentuan subjek (Informan) berdasarkaan kriteria dan tujuan dari penelitian ini. Kriteria dan tujuan dari penelitian ini. Kriteria ini ditentukan oleh peneliti, dimana yang dipilih Kepala Bagian Marketing Manajer PT. Bank Rakyat Indonesia (Persero) Tbk. Kcp Bambaloka. Yang beralamat Kelurahan Bambaloka, Mamuju Utara, Sulawesi Barat dengan tidak berdasarkan jenis kelamin dan mereka siap menjadi informan. Informan yang digunakan adalah 1 (satu) orang dan memungkinkan adanya penambahan jika Tujuan penelitaian belum tercapai. Tahapan untuk memperoleh informal adalah :

1. Peneliti mencari informal marketing manajer sesuai kebutuhan peneliti.

2. Peneliti kemudian menyeleksi calon informan tersebut dengan melihat kesesuaian kriteria. Dan juga berdasarkan sifat keterbukaan informan.

3. Peneliti mengajukan pertanyaan untuk kesediaan mereka melakukan wawancara dan observasi dibuktikan dengan lembar kesediaan menjadi informan. 


\section{INSTRUMEN PENELITIAN}

Instrumen penelitian yang digunakan bentuk pertanyaan terbuka, pertanyaan dimulai dengan identifikasi informan. Dimana pertanyaan utamanya merupakan pertanyaan yang mengarah pada strategi yang digunakan bauran pemasaran. Pertanyaan tambahan selanjutnya dimungkinkan dari gambaran yang diberikan informan selain pertanyaan utama seperti yang dijelaskan sebelumnya. Adapun hal yang ditanyakan:Strategi pemasaran apakah yang digunakan dalam meningkatkan kepuasan nasabah tabungan pada PT. Bank Rakyat Indonesia (Persero) Tbk. Kcp Bambaloka?

1. Bagaimana cara menentukan strategi pemasaran yang digunakan dalam meningkatkan kepuasan nasabah tabungan pada PT. Bank Rakyat Indonesia (Persero) Tbk. Kcp Bambaloka. ?

2. Bagaimana cara implementasikan strategi pemasaran yang digunakan dalam meningkatkan kepuasan nasabah tabungan pada PT. Bank Rakyat Indonesia (Persero) Tbk. Kcp Bambaloka. ?

3. Bagaimana proses evaluasi strategi pemasaran yang digunakan dalam meningkatkan kepuasan nasabah tabungan pada PT. Bank Rakyat Indonesia (Persero) Tbk. Kcp Bambaloka. ?

4. Bagaimana cara menentukan strategi pemasaran yang digunakan dalam meningkatkan kepuasan nasabah pada PT. Bank Rakyat Indonesia (Persero) Tbk. Kcp Bambaloka?

Keseluruhan ini pertanyaan tersebut akan diselaraskan dengan Strategi pemasaran yaitu: Strategi Superior Custumer Service, Relationship Marketing Strategy, Strategi penanganan keluhan yang efektif. 


\section{DEFINISI OPERASIONAL VARIABEL}

1. Relationship Marketing Strategy hubungan transaksi antara penyedia jasa dan pelanggan berkelanjutan, tidak berakhir setelah penjualan selesai, Adapun indikatornya yaitu:
a. Menjalin hubungan jangka panjang.
b. Menekankan upayan pemeliharaan komitmen dan pemenuhan janji.
c. Mempertahankan nasabah.
d. Memenuhi kebutuhan nasabah.

2. Strategy Superior Custumer Service, berusaha menewarka pelayanan yang lebih unggul dari pada para pesaing. Adapun indikatornya yaitu :
a. Memberikan jaminan keamanan dana nasabah
b. Memberikan fasilitas pelayanan

3. Strategi Unconditional Guarantees, Komitmen untuk memberikan kepuasan kepada pelanggan yang pada gilirannya akan menjadi sumber dinamisme penyempunaan kualitas jasa dan kinerja perusahaan. Adapun indikatornya yaitu :
a. Mengembangkan augmented service terhadapat core Service
b. Komitmen untuk memberikan kepuasan.

4. Strategi peningkatan kinerja perusahaan. Penanganan keluhan yang lebih baik memberikan peluang untuk mengubah seorang pelanggan yang tidak puas menjadi tidak puas. Adapu indikatornya yaitu :
a. Penyedia jasa bisa terhindar dari publisitas negatif.
b. Penyedia jasa akan mengetahui aspek-aspek yang perlu dibenahi dalam pelayanannya saat ini.

c. Penyedia jasa akan mengetahui sumber masalah operasinya. 


\section{ANALISIS DATA}

Metode analisis data digunakan dalam penelitian ini adalah metode analisis deskriptif kualitatif yang menguraikan strategi yang digunakan untuk meningkatkan kepuasan nasabah tabungan pada PT Bank Rakyat Indonesia (Persero) Tbk. Kcp niaga daya

\section{Pendekatan Penilaian}

Penelitian ini yang dilakukan dengan menggunakan metode penelitian kualitatif, yang digunakan untuk meneliti pada kondisi objek kunci, teknik pengumpulan data yang dilakukan secara triangulasi (observasi, wawancara, dokumentasi), data yang di peroleh cenderung data kualitatif. Analisis data bersifat induktif/kualitatif, dan hasil kualitatif bersifat untuk memahami makna, memahami keunikan, mengkonstruksi, fenomena, dan menemukan hipotesis (Sugiyono, $2017: 9$ ).

\section{Pendekatan Kualitatif Naratif}

Pendekatan kualitatif naratif yang merupakan pendekatan yang dilakukan dengan mempelajari perjalanan kehidupan dari satu orang atau lebih yang kemudian dirangkum dan disusun oleh penelitian menjadi satu laporan yang naratif dan kronologis (Sugiono, 2017:162)

Langkah-langkaah dari analisis data yang dilakukan adalah :

a. Mengorganisasikan dan menyiapkan data yang akan dianalisis.

Data menta yang akan dianalisis diorganisasikan berdasarkan tanggal pengumpulan data, sumber data, jenis data, deskripsi data, sifat data

b. Baca dan lihat seluruh data

Peneliti harus membaca seluruh data yang dikumpul, supaya dapat mengetahui data apa saja yang telah diperoleh sumber data dan maknanya. 
c. Membuat koding seluruh data

Koding adalah proses memberikan tanda terhadap data yang telah dikelompokkan. Kelompok data yang sejenis diberi kode yang sama. Koding dapat dilakukan secara manual atau dengan computer.

d. Membuat koding seluruh data

Melalui koding, peneliti menghasilkan tema-tema atau kategorisasi data penelitian yang merupakan temuan, Berdasarkan tema-tema yang dihasilkan tersebut, selanjutnya peneliti membuat deskripsi secara singkat yang sistematis sehingga tema-tema yang ditemukan menjadi lebih jelas.

\section{KESIMPULAN}

Strategi adalah hal penting bagi kelangsungan hidup dari suatu perusahan untuk mencapai sasaran atau tujuan perusahaan yang efektif dan efisien, perusahaan harus bisa menghadapi setiap masalah-masalah atau hambatan yang datang dari dalam perusahaan maupun dari luar perusahaan.

Kepuasan nasabah Salah satu tujuan utama perusahaan jasa dalam hal ini adalah menciptakan kepuasan nasabah, sebagai hasil penilaian terhadap apa yang diharapkannya dengan membeli dan mengomsumsi suatu produk atau jasa.

Kepuasan pelanggan menurut Kotler and Keller, (2007) adalah tingkat perasaan seseorang setelah membandingkan kinerja peoduk (atau hasil) yang ia rasakan dengan harapan yang kita miliki. 


\section{DAFTAR PUSTAKA}

Chan, Syafruddin, 2003. Relationship Marketing : Inovasi Pemasaran yang Membuat Pelanggan Bertekuk Lutut. Cetakan Kedua. Jakarta : Penerbit Gramedia Pustaka Utama

David, R. Fred, 2011. Strategic Management. Edisi sepuluh. Jakarta, Salemba Empat.

Jurini, K.P.M, 2003. "Menetapkan Segmentasi Pasar, Bagian Proyek Pengembangan Kurikulum Direktorat Pendidikan Menengah Kejujuran” Depdiknas.

Kasmir, 2008, 2008. Bank dan Lembaga Keuangan Lainnya. Edisi Revisi 2008.

Jakarta: PT. Raja Grafindo Persada.

Kotler, Philip, 2003. Marketing Management, 11 th Edition, Prentice Hall, New Jersey.

Munadi, F. Ahmad, 2009. "Analisis Strategi Pemasaran untuk Meningkatkan Penjualan Kendaraan Motor pada CV Turangga Mas Motor", Jurnal Ekonomi, Universitas Gunadhama.

Siagian, P. Sondang, 2004. Manajemen Sumber Daya Manusia. Jakarta, Bumi Aksara.

Supranto, 2001. Pengukuran Tingkat Kepuasan Pelanggan. Cetakan Kedua. Edisi Baru. Rineke Cipta. Jakarta.

Wijayanti, Ari, 2008. "Strategi Meningkatkan Loyalitas Melalui Kepuasan Pelanggan Studi Kasus: Produk Kartu Seluler PraBayar Mentari-Indosat Wilayah Semarang", Jurnal Manajemen Pemasaran, Vol 4, No 2:45-60. 
Kotler, Philip dan Kevin Lane Keller, 2006 , Marketing Management, Pearson Education Inc.

Sugiyono 2017. Metode Penelitian Kualitatif Kualitatif, R\&D Bandung: Alfabeta. 
Anggito, Albi dan Setiawab, Johan. 2018. "Metode Penelitian Kualitatif". CV Jejak

............. 2017. Metode Penelitian Kualitatif Kualitatif , dan R\&D Bandung :

Alfabeta CV

Sugiyono,2010. Metode Penelitian Pendidikan Pendidikan Kualitatif, dan R\&D. Bandung Alfabeta

Daga Rosnaini, 2017. Straregi Meningkatkan Kepuasan Nasabah Tabungan Pada PT. Bank Perkreditan Rakyat Hasa Mitra Cabang Makassar. Jurnal Akmen , Vol 14 no:3

Yusuf, Muhammad 2019,Analisis Tingkat Kepuasan Nasabah Dalam Menggunakan Transaksi Tunai Pada PT. Bank Mandiri (Persero)Tbk. Ratulangi, Makassar. 
